\title{
World Christianity and the Reorganization of Disciplines: On the Emerging Dialogue between Anthropology and Theology
}

\author{
Joel Robbins
}

What are the prospects for a dialogue between anthropology and theology? ${ }^{1}$ The stress on dialogue is important here. Surely there have already been many theologians who have read anthropological works and put them to use for their own purposes, and in recent years a few anthropologists have begun, at least tentatively, to do the same with theology. But this is not what I mean by dialogue in the present context. What we mostly have now is more a matter of scholars finding some new means to help them reach ends they have long held. I have, for example, sometimes found myself disappointed when reading works in which theologians enthusiastically take up ethnography as a method for studying their own home communities, often enough their own churches, and count that as an engagement with my discipline. Too often, they want to use ethnography to document things they already knew were present in the situations they studied - such as that the voices of some members of their communities are not routinely heard by others, or that religious practice is fundamental to religious life and thought. It is not that these are not important findings; they just are not the kind of findings that theologians particularly need anthropology in order to produce. And more than this, they are not the kinds of findings that anthropologists have generally, at least until recently, wanted their fieldwork to generate - the kinds of findings one had not even guessed were out there in the world when one started out on one's research. ${ }^{2}$ These are findings like the fact that, in many societies of the South Pacific, people insist that they cannot ever have any idea of what other people are

1 A slightly shorter version of this chapter was published in 2018 in the book Theologically Engaged Anthropology, edited by Derrick Lemons and published by Oxford University Press. I thank Dr. Lemons and Oxford University Press for permission to publish a lightly expanded version here.

2 John Borneman and Abdellah Hammoudi, "The Fieldwork Encounter, Experience, and the Making of Truth: An Introduction," in Being There: The Fieldwork Encounter and the Making of Truth, eds. J. Borneman and A. Hammoudi (Berkeley: University of California Press, 2009), 1-24. 
thinking and consistently act accordingly; ${ }^{3}$ or that there exists a group of people who are very attached to, and deeply moved by, a ceremony in which dancers sing all night about their hosts' recently deceased relatives until the hosts burn them severely and repeatedly with resin soaked torches, forcing them to stop; ${ }^{4}$ or that some women who take up "sex-work" in Papua New Guinea do so not for the small amounts of cash they sometimes earn but to protest the fact that their fathers and brothers have given up pursuing traditional bridewealth payments from the men they marry. ${ }^{5}$ Without the motive of finding out surprising things like this about ways of living one never imagined, ethnography may retain some of its strengths as a method, but not as a specifically anthropological one. So, when theologians tell me that what they love about anthropology is ethnography, I am often inclined to point out that this is like telling us you love us for our money - for the means we can provide to reach ends we have no part in defining. I am sure that some anthropological uses of theological ideas look this way to theologians as well. In personal terms, this instrumentally defined love is not the kind of love people look for, and in intellectual terms, it is not the right starting point for the kind of dialogue I am hopeful might grow up between theology and anthropology.

The kind of dialogue I am looking for is one that would in some ways, perhaps surprising ways, transform each discipline; that would make some contribution to expanding each discipline's sense of its ends, and not just to augmenting its means of attaining them. This type of interdisciplinary encounter has happened for anthropology before. The dialogue with linguistics that produced anthropological structuralism, for example, fundamentally redefined the kinds of meaningful orders anthropologists aimed to discover in social life. A more recent encounter with the discipline of history upended our sense of the basic temporal nature of the things we study. And notably, anthropology has rung some changes in some branches of linguistic and historical research as well, so the dialogue has been two-way. Even at my, as yet, rudimentary state of knowledge, it seems safe to say that theology has over the centuries had a number of these kinds of goal-post moving encounters with philosophy, where both disciplines have been deeply shaped by the other. Is there a chance to develop this kind of conversation between anthropology and theology now? That is the question I would like to raise here.

3 Joel Robbins, "On Not Knowing Other Minds: Confession, Intention, and Linguistic Exchange in a Papua New Guinea Commnuity." Anthropological Quarterly 81, no. 2 (2008): 421-429.

4 Edward L. Schieffelin, The Sorrow of the Lonely and the Burning of the Dancers (New York: St. Martin's Press, 1976).

5 Holly Wardlow, Wayward Women: Sexuality and Agency in a New Guinea Society (Berkeley: University of California Press, 2006). 
In exploring possible answers to this question, I am going to pursue two avenues of investigation. The first briefly reviews recent changes in both disciplines and suggests that these changes bring them to a point where in fact their paths are ready to cross. The change in anthropology I want to consider is the unexpectedly rapid rise of what is called the anthropology of Christianity. The change in theology and religious studies is the recent advent and rapid mainstreaming of the notion of "global" or "world" Christianity. Why did these changes occur? What new kinds of thinking have they afforded? And crucially for my concerns in this paper, how might they open theology and anthropology to new kinds of encounters with one another?

The second avenue I want to go down looks at one kind of Christianity that I think anthropologists and theologians alike find it difficult to grapple with this is the prosperity gospel, in which believers are convinced that God wants health and wealth for them in this world, and they overwhelmingly stress these themes in their worship. Scholars in the Western academy, at least, tend to find this kind of Christianity hard to assimilate to their more general understandings of the faith, or at least to their favorite understandings. My wager is that a closer look at how this kind of Christianity trips up both theologians and anthropologists may reveal places where both disciplines would be open to help from each other, the provision of which might lay the basis for the kind of transformative dialogue I am calling for here. With this outline in place, let me begin by looking at how anthropologists came to study the Christian faith and theologians began to think about something they have come to call "world Christianity."

Anthropology Discovers Christianity, Theology Discovers the World

In discussing the rise of the anthropology of Christianity and the advent of the notion of world Christianity, it is worth noting at the outset that both happened around the same time - starting from the second half of the 1990s. They were, as far as I can tell, independent developments. But I think it is true that both were responses to some of the same changes in the world, and for this reason the basis for claiming they might be relevant to one another has been there from the start. Let me first offer brief accounts of how the anthropology of Christianity and the idea of world Christianity came about, and then I will return to issue of their shared origins in our changing world.

If you were to discover the extensive literature that anthropologists have produced about Christianity by 2019, you could be forgiven for imagining that they had been avidly studying Christian groups for a long time. But if you 
looked a little more closely, you would discover that this first impression is misleading. You only have to go back 20 years, to the mid-199os, to find the discipline of anthropology looking radically different. At that time, there were some excellent ethnographic studies of Christianity around, particularly from the hands of scholars working in Africa, and even a couple of edited volumes on the subject published in hard to find editions. But there was nothing like the outpouring of work one finds today and, more importantly, there was no sense of a shared anthropological project to which research on Christians around the world could contribute. ${ }^{6}$ Africanists wrote about Christianity assuming they spoke to their Africanist colleagues; Mediterraneanists wrote for Mediterraneanists and so on.

It was in conscious opposition to this status quo that a group of younger scholars began, near the turn of the millennium, to argue that given how many Christians there are in the world, anthropologists really ought to be studying Christianity more regularly, and, as importantly, that they ought to do so in conversation with one another, working to develop a distinctively anthropological approach to Christianity and turning their findings to use in helping to make novel theoretical claims of relevance to the whole discipline. Some theoretically generative themes quickly fell into place, turning around questions like the extent to which Christian conversion among previously non-Christian populations tends to foster unusually radical cultural change; the frequency with which Christianity leads people to explore new forms of individualism that move them in "modernizing" directions; whether one of Christianity's most profound effects is a fundamental transformation of people's notions of language; and if Christianity is invariably a religion focused on transcendence. ${ }^{7}$ All of these topics and more have been at the center of vigorous debates, and anthropologists have quickly joined them on the basis of studies from all over the world, from Eastern Europe to Latin America, from the South Pacific to Asia, from North America to Africa. Currently, the anthropology of Christianity is well established as one of the major trends in the 21st-century discipline.

6 For reviews of some current work that reflects the development of this kind of shared project around the study of a number of topics in the study of Christianity see Joel Robbins, "Transcendence and the Anthropology of Christianity: Language, Change, and Individualism" (Edward Westermarck Memorial Lecture, October 2011), Journal of the Finnish Anthropological Society 37, no. 2 (2012): 5-23; Joel Robbins, "The Anthropology of Christianity: Unity, Diversity, New Directions" (An Introduction to Supplement 10), Current Anthropology 55 (S10) (2014): S157-S171.

7 Robbins, "Transcendence." 
A natural first question to ask, in light of how quickly the anthropology of Christianity has grown, was why it was so late to get off the ground. ${ }^{8}$ Many answers have been proposed to this question, of which I will only mention one today. From the outset anthropology defined itself as the study of "other" cultures, and Christianity was, for many anthropologists, at the very center of the cultures from which they came. If we add to this the fact that many anthropologists initially turn to the study of other cultures because they are at least gently alienated from their own, or deeply reflexive about it, then it is clear that for them Christianity is not the kind of thing they want to study. It is little wonder, then, that Christianity became something like a taboo topic for the discipline - what Susan Harding9 memorably called a "repugnant cultural other" for a crowd that otherwise prided itself on it radical openness to different ways of life.

Given this and other strong impediments to the development of an anthropology of Christianity, a second question to ask is why it took off when it did. There are many approaches to this question too, but most of them turn around the issue of whether it was changes in anthropology as a discipline that made the rise of the anthropology of Christianity possible, or whether it was changes in the world anthropologists study. ${ }^{10}$ In this case, saying it was both is not a cop out. On the side of changes internal to anthropology, one has to note that the advent of the anthropology of Christianity came right on the heels of a period of intense disciplinary questioning of the epistemological, political, and ethical difficulties that attend studying the "other." In the wake of decolonization and the wave of postcolonial thought that followed, along with the rapid turn to identity politics throughout the West, by the 1980s "speaking for others" or even "about" them became deeply problematic, and anthropologists quickly began to critically scrutinize and dismantle their self-understanding as practitioners of a discipline that defined itself primarily as a science of otherness. The anthropological turn to the study of Christianity thus arose just as the otherness test for suitability as an anthropological object - the very test that Christianity had always failed to pass - had been discarded.

So, anthropology had been changing from within for a while by mid-199os, but at the same time this internal ferment was taking place, many of the paradigmatically "other" places in the world that past anthropologists had tended

\footnotetext{
8 Robbins, "The Anthropology of Christianity."

9 Susan Harding, "Representing Fundamentalism: The Problem of the Repugnant Cultural Other," Social Research 58, no. 2 (1991): 373-393.

10 Bronwen Douglas, "From Invisible Christians to Gothic Theatre: The Romance of the Millennial in Melanesian Anthropology," Current Anthropology 42, no.1 (2001): 615-650.
} 
to study were also changing in ways that helped push for the development of an anthropology of Christianity. One key development at this time was the explosive growth of Pentecostal and charismatic Christianity. What I will henceforth simply call Pentecostal Christianity for ease of expression is that strand of the faith in which believers hold that the gifts of the Holy Spirit - gifts such as speaking in tongues, healing, prophesying, and delivering the afflicted from spiritual bondage - are potentially available to everyone to be used in ways that affect earthly life. Having come into existence only in the early 19oos, by the first decade of the current century credible estimates suggest Pentecostalism has 500 million adherents, representing a quarter of the world's total Christian population. ${ }^{11}$ From the 1960s onward, much of this growth has occurred in the traditional anthropological stomping grounds of Asia, Africa, Latin America, and the South Pacific. All of a sudden, anthropologists were finding Pentecostals everywhere they went. And as a form of the faith with a very active public ritual presence, and one that insists on the relevance of religion for all aspects of life, anthropologists who encountered Pentecostalism in the course of their research were unable to ignore it easily. It is little surprise then that much of the early work in the anthropology of Christianity took up Pentecostalism, insisting that ethnography had to reflect its centrality in the lives of those who converted to it. Indeed, the early anthropology of Christianity was often criticized for being too heavily focused on Pentecostalism. ${ }^{12}$ That problem has abated - there are now large and growing anthropological literatures on most kinds of Christianity - but it is fair to say that the global growth of Pentecostalism had a lot to do with the initial anthropological turn to studying Christianity more generally by, as it were, forcing the issue on many anthropologists who, like myself, might have gone to the field imagining they were going to study something else.

Having brought up Pentecostalism's dramatic growth throughout the second half of the 2oth century, this is a good point at which to turn to the second scholarly development I want to chart, for the construction of the notion of "world" or "global" Christianity is also in part a response to this phenomenon. The terms "world Christianity" and "global Christianity" trip so easily off the tongue today, and there is so much institutional support for their use in the form of courses, named chairs, conferences and publications of all sorts that

11 Katherine Attanasi, "The Plurality of Prosperity Theologies and Pentecostalism," in Pentecostalism and Prosperity: The Socio-Economics of the Global Charismatic Movement, eds. K. Attanasi and A. Yong (New York: Palgrave, 2012), 2.

12 Brian Howell, "Practical Belief and the Localization of Christianity: Pentecostal and Denominational Christianity in Global/Local Perspective," Religion 33, no. 3 (2003): 233-248. 
deploy them, that it is easy to forget that as features of common parlance they are no older than the anthropology of Christianity. ${ }^{13}$ And of course, they are not mere terminological innovations, for they index the development of what Mark Shaw calls "both a perspective and a discipline."14

In his contribution to a new Baker Academic book series entitled Turning South: Christian Scholars in an Age of World Christianity, the historian of Christianity Mark Noll15 elegantly narrates how he grew up during the 1950s and early 196os in a Baptist household in the Midwest of the United States that featured a world map in the dining room dotted with pins marking the locations in which missionaries that their church supported were working. Yet this choice of household decoration did not, he goes on to note, lead him to consider "how important the world as a whole actually was for the history of Christianity." It was only during the 1990s that he made a shift to recognizing the existence of a world Christianity that was not an exclusive product of the West and its traditions, and only in 2000 that he began regularly teaching courses in this subject. ${ }^{16} \mathrm{He}$ then goes on to note that "Changes even in the short span of years since 2000 indicate how very rapidly 'world Christianity' has become....an extraordinarily active venue for research, interpretation, controversy, and discussion."17 Like many others, Noll credits a few scholars, all theologians and/ or historians of mission like Andrew Walls, Lamin Sanneh, and Dana Robert, with being out ahead of himself and others in recognizing that something novel enough to deserve a new coinage like "world Christianity" had come into being at increasing speed over the course of the latter part of the 2oth century. But as a genuine academic trend, he confirms that the wide scholarly embrace and development of this notion is only about 20 years old, its first great breakthrough into wider consciousness marked by the great academic and popular success of Philip Jenkins' highly accessible 2002 book The Next Christendom: The Coming of Global Christianity and the widely read digest of it that featured in the popular US magazine The Atlantic.

For the many scholars who have come to embrace the idea of world Christianity, the resulting change in their view of things amounts to something like a Kuhnian paradigm shift. When one sees the world through the lens of what the

\footnotetext{
13 See Robert Wuthnow, Boundless Faith: The Global Outreach of American Churches (Berkeley: University of California Press, 2009).

14 Mark Shaw, "Robert Wuthnow and World Christianity: A Response to Boundless Faith." International Bulletin of Mission Research 36 no. 4 (2012): 179.

15 Mark A. Noll, From Every Tribe and Nation: A Historian's Discovery of the Global Christian Story (Grand Rapids: Baker Academic, 2014), 2.

16 Noll, From Every Tribe, 110.

17 Ibid., 113 .
} 
sociologist Robert Wuthnow ${ }^{18}$ in fact calls the "Global Christianity paradigm," several phenomena and claims move from the periphery to the center of one's concerns. First, there is the fact that in statistical terms, the greatest recent growth of Christianity, driven in important respects by the same growth of Pentecostalism that has captured anthropological attention, has not been in its traditional strongholds of Europe, North America, and their settler colonies, but rather in what adherents call the Global South. As Robert ${ }^{19}$ summarizes this point, in terms that have been oft repeated, "The typical late twentiethcentury Christian was no longer a white man, but a Latin American or African woman." Second there is the way that patterns of missionization are changing, with more and more missionaries moving from the South to the South and from the South to the North, sometimes with the kind of spectacular results the Nigerian Sunday Adelaja has had in founding what was at one time the largest church in Eastern Europe ${ }^{20}$ or the Brazilian Universal Church of the Kingdom of God has had in spreading throughout the world since its founding in $1977 .{ }^{21}$ And finally there is the key claim that the influence of "Southern" Christian theology and practice will more and more come to shape the future of Christianity, with Western traditions having to accept their less dominant role. Recent struggles over sexuality in the Anglican communion are often taken as indicative of the kinds of global interactions likely to shape Christianity in the future, and the impressive "Pentecostalization" that has led worship at many Northern churches to at least sometimes come to resemble the kind of worship that is so prevalent in other parts of the world is another. To speak of world or global Christianity, then, has come to mean seeing the trends I mention as crucial to the contemporary faith - a view of the faith that sees it as global not just in its reach, but in the factors driving its development.

Whenever a major new paradigm or research program emerges, disciplinary space gets rearranged. Students find themselves interested in new topics, funding and hiring priorities shift, new journals take off. What I have wanted to suggest thus far is that theology and the broader study of Christianity has lately

18 Wuthnow, Boundless Faith.

19 Dana L. Robert, "Shifting Southward: Global Christianity Since 1945." International Bulletin of Mission Research 24, no. 2 (2000): 50.

20 Nimi Wariboko, "Pentecostal Paradigms of National Economic Prosperity in Africa," in Pentecostalism and Prosperity: The Socio-Economics of the Global Charismatic Movement, ed. Attanasi and A. Yong (New York: Palgrave, 2012), 51.

21 Eloy H. Nolivos, "Capitalism and Pentecostalism in Latin America: Trajectories of Prosperity and Development." In Pentecostalism and Prosperity: The Socio-Economics of the Global Charismatic Movement, eds. K. Attanasi and A. Yong (New York: Palgrave, 2012), 98. 
undergone a space-shifting change of this kind to accommodate "world Christianity" during just the period that anthropology has undergone a similar one with the growing disciplinary interest in Christianity. Both fields are thus in some transition. What I now want to consider is how the upheavals both disciplines have experienced might bring them to the kind of transformative dialogue I called for at the outset of this chapter.

In this second part of my discussion, my tone will shift. I feel confident about the histories of recent disciplinary transformation I have just recounted, but the anthropology-theology dialogue itself is so new that there are no settled positions I can report. So instead of reviewing firm findings or proven approaches to putting anthropology and theology productively to work together, I will turn to examining an expression of Christianity with which I think scholars in both camps struggle to come to grips. By gathering around a version of the faith about which neither group is given to confident pronouncements, I hope we might discover some ways we can be relevant to one another.

The expression of Christianity I have in mind is the prosperity, health and wealth, or word-faith gospel. Preachers in this tradition exhort their congregants to recognize that God has promised them, indeed through Christ's atonement has contractually obligated himself to provide them with, material plenty and good health on earth. All they need do to claim what is rightfully theirs is believe strongly, tithe regularly, and claim from God, or, as movement jargon has it, positively confess to Him what it is they want and need. It is fitting in the present context that the prosperity gospel developed in part out of the same Pentecostal movement that has done so much to bring both the anthropology of Christianity and the notion of world Christianity into being. And its spectacular growth in many of the same places in which Pentecostalism is expanding has made it a force that scholars working in both fields cannot ignore. At the same time, however, it has often been hard for such scholars to welcome the prosperity gospel into their visions of the Faith, and this no matter how broad such visions have recently become.

Many responses to the prosperity gospel from both quarters have been flatly negative in their evaluations of what many take to be a form of Christianity that preys on the poor and needy, taking the little that believers have in tithes extracted through the cultivation of false hopes of spectacular return. 
Pentecostal theologian Robert Bowman, ${ }^{22}$ for example, called the prosperity gospel "Pentecostalism at its (near) worst," and Rob Starner, ${ }^{23}$ another Pentecostal theologian, defines it as "a sword of division within the ranks of Christendom." Martyn Percy, ${ }^{24}$ sociologist and theologian, suggests that the prosperity gospel is more prone than many other strands of Christianity to becoming "abusive religion." In anthropology too, with the brave exception of Simon Coleman's ${ }^{25}$ work on a well-known Swedish prosperity church, most of those willing to risk joining the new move to studying Christianity still seemed to find prosperity gospel churches to be a repugnant other, and most have managed to steer clear of them. Of those anthropologists who have taken notice of the prosperity gospel's increasing influence, many follow the Comaroffs ${ }^{26}$ in lumping it in with what they call, following Evans-Pritchard, forms of "new magic" such as witchcraft beliefs that hold that witches kill in order to create zombie workforces under their own control. Folded in with such "magical" trends, the prosperity gospel figures as a component of what the Comaroffs ${ }^{27}$ call "occult economies," phantasmagoric cultural formations that they argue represent people's failed attempts to understand the complex new neo-liberal global economy they have been forced to join, or try to join, but cannot really comprehend. This approach makes no attempt to reckon with the specificities of the prosperity gospel as an outgrowth of the Christian tradition and as a faith that both leaders and followers are highly committed to seeing as still within its borders.

But even as such frankly negative responses to the prosperity gospel have been influential in both anthropology and theology, there have also recently appeared more sober assessments of this form of faith. What is of interest here is the different shapes these reconsiderations have taken in each discipline, for these differences reveal some unexpected common ground between the two fields even as they also highlight what is one of the most profound differences.

22 Cited in Glyn J. Ackerley, Importing Faith: The Effect of American "Word of Faith" Culture on Contemporary English Evangelical Revivalism (Eugene, Oregon: Pickwick Publications, 2015), 20.

23 Rob Starner, "Prosperity Theology." In Encyclopedia of Pentecostal and Charismatic Christianity, ed. S.M. Burgess (New York: Routledge, 2006), 392.

24 Martyn Percy, "Forward," in Importing Faith: The Effect of American "Word of Faith" Culture on Contemporary English Evangelical Revivalism, ed. G.J. Ackerley (Eugene, Oregon: Pickwick Publications, 2015), vii.

25 Simon Coleman, The Globalisation of Charismatic Christianity: Spreading the Gospel of Prosperity (Cambridge: Cambridge University Press, 2000).

26 Jean Comaroff and John L. Comaroff, "Occult Economies and the Violence of Abstraction: Notes from the South African Postcolony." American Ethnologist 26, no. 2 (1999): 279-303. Comaroff and Comaroff, "Occult Economies." 
Let me start with anthropology. Amongst themselves anthropologists often joke that one reason they have trouble capturing the attention of a wide public, even on issues about which they clearly have something to say, is that their answer to every question tends to be, "Well, it's complicated."28 The serious point buried in this self-deprecatory observation is that anthropology at its best looks at how the different parts of a cultural formation are tied together in knots that often are in fact quite intricate; anthropologists insist that when one does so none of the parts appear to be freakish or bluntly "irrational," nor do they evidence the simple ignorance of those who live in light of them. Even the prosperity gospel emerges as susceptible to this treatment. On careful analysis, it usually turns out to be more than merely a confused attempt to construe the neo-liberal world or a sop to people's worst selfish tendencies, standing instead as a cultural phenomenon that fosters meaningful links between the various values by which believer's aim to live their lives.

One of the best examples of this approach to the prosperity gospel is the anthropologist Naomi Haynes' 29 work on the Zambian Copperbelt. By the time Haynes began her fieldwork in 2006, the economic boom times that once characterized Copperbelt life were long over. If not destitute, the people she studied were certainly not well off, and they were much poorer than they or their parents' generation had expected they would be. The economic ground having shifted underneath their feet, one might see these Zambians' turn to prosperity churches, of which there are hundreds in the town Haynes studied, as representing just the kind of desperate grab at a simplistic and faulty framework for understanding the harsh new world they inhabit that some anthropologist would expect them to make. But Haynes' analysis does not follow this line. Instead, she focuses on one of the features of these churches that scholars often find discomfiting - their strongly hierarchical structure that elevates pastors, as models of God-given success and conduits of divine power, high above their flocks - in order to explore their fit with core Zambian concerns. Through careful cultural and historical analysis, Haynes shows that Zambians have always favored the creation of patron-client relationships that connect people across differences in power and resources. To participate in such links is, as they told her, to realize the value of "moving" ahead socially - the value that they find it most important to pursue. In their churches, when they pray for blessings and

28 See Webb Keane, "Self-Interpretation, Agency, and the Objects of Anthropology: Reflections on a Genealogy," Comparative Studies in Society and History 45 (2003): 222-248.

29 Naomi Haynes, "Pentecostalism and the Morality of Money: Prosperity, Inequality, and Religious Sociality on the Zambian Copperbelt," Journal of the Royal Anthropological Institute 18 (2012): 123-139. 
breakthroughs, it is this kind of movement they hope to produce. And often they do produce this value in their Christian lives, for the fostering of relations with powerful pastors, and through them with the Holy Spirit and God, constitute success in this endeavor. Prosperity here is not the fulfillment of selfish, neo-liberally informed individual desires for material goods for their own sake, but instead, as Haynes puts it, a relationally expansive kind of advancement that puts Copperbelt prosperity churches at the center of people's efforts to build community during materially difficult times.

Haynes is not alone in finding that prosperity gospel church life is "more complex" than one might expect at first glance. In a recently published article based on fieldwork with emerging prosperity gospel prophets and pastors in urban Ghana, Girish Daswani ${ }^{30}$ argues that far from the amoral, neo-liberal profiteers so many imagine these figures to be, the men he worked with are deeply committed to evaluating their own characters and those of the more established Christian leaders with whom they train in ethical terms. Key to their evaluations is an ethical distinction they make between being a "wealthy" Christian and being a "rich" one. ${ }^{31}$ Rich pastors and other rich Christians seek fame for their own aggrandizement and material success for their own enjoyment. The wealthy, by contrast, put their fame and their resources in the service of helping others, redistributing what they gain from their religious success. Again, we see that "prosperity" here is not a simple notion, and that the prosperity gospel is not, as those who treat it as a kind of magic tend to imagine, always without ethical import.

One thing that is common to Haynes' and Daswani's work, and to that of many other anthropologists studying the prosperity gospel, is that both authors strive to adopt the generally non-judgmental stance that has, at least until recently, been a hallmark of anthropological writing. Even as they do not pronounce on the value of prosperity churches in relation to some clear standard, they are concerned, as anthropologists always are, to show that the church members that they study do not live less than human lives, devoid of intelligence or social and moral concern. Everyone, as the old relativist saw has it, makes sense in their own terms. Haynes and Daswani show us that this is as true of prosperity gospel followers as it is of anyone else. But the disciplinary centrality of this goal of rendering those we study in complicated, fully human terms can leave anthropologists tongue tied in cases where they worry they cannot reach it. In my experience, this happens very rarely - or when it does,

30 Girish Daswani, "A Prophet but not for Profit: Ethical Value and Character in Ghanaian Pentecostalism," Journal of the Royal Anthropological Institute 22 (2015): 108-126.

$31 \quad$ Ibid., 109. 
anthropologists abandon the project at hand and news of the failure never reaches the literature. But recently, one anthropologist has found herself in this position vis-à-vis her fieldwork in a prosperity gospel church and has had the courage to write a major anthropological study in spite of the difficulties her situation presents.

Ilana van Wyk carried out ethnographic fieldwork in the Universal Church of the Kingdom of God in Durban, South Africa. I mentioned the Universal Church earlier. It is widely known as one of the paradigm cases of successful cultural/religious globalization from the South to the South and the North. Since its founding in Rio de Janeiro, Brazil, in 1977, the Universal Church has spread to at least 60 countries, and in 2005 it was opening a new church every week in South Africa alone. ${ }^{32}$ The Universal Church is solidly in the prosperity tradition, promising followers that their strong faith and generous tithes will result in their substantial enrichment. Like many other prosperity churches, it adds to this a core emphasis on the claim that one reason church-goers sometimes fail to prosper is that they are blocked by demons who hold them down. Much of church practice therefore takes the form of spiritual warfare aimed at "binding" and vanquishing such demons so that members will be free to achieve success.

The book van Wyk ${ }^{33}$ wrote on the basis of her fieldwork is entitled The Universal Church of the Kingdom of God in South Africa: A Church of Strangers. For our purposes, the subtitle of the book reveals its core argument. The church in Durban, she shows in great detail, does nothing to build community among its members - there are no small groups, little by way of development projects or charitable good works, and the leadership of the church moves pastors regularly to prevent them becoming too close with those who attend services. More than this, sermons regularly focus on the claim that demons set to block believers' access to God's bounty can deceitfully take the form of people they might find appealing, such as those sitting next to them in the pews. It is not surprising, then, that church members mostly keep to themselves and even the relatively small numbers who attend the church year after year tend to have few relationships with other members. Alongside the isolating talk of demonic omnipresence, demands for tithes and other gifts to the church are constant and sometimes accompanied by threat; one pastor even insisted that "old women who hid money in their bras for the taxi fare home would be killed or maimed en route, while parents who paid school fees instead of tithes would

32 Nolivos, "Capitalism," 98-99; Ilana van Wyk, The Universal Church of the Kingdom of God in South Africa: A Church of Strangers (Cambridge: Cambridge University Press, 2014), 13. 
see their children fail or die." ${ }^{34}$ Such tactics are deployed in a context where the gifts many of the very poor congregants give serve to estrange them from their families, who are enraged by the diversion of what little funds are available from pressing household needs. It is hard to escape the suspicion that we are here in the presence of Percy's "abusive religion" - a hard case for the anthropological impulse to dwell on complication and strive to make sense of people's lives in the round.

It is to van Wyk's credit that she acknowledges the difficulty this church presents to her as an anthropologist. In her book, she is open in her dislike of the church, and she has written a searching article in which she counters the often implicit anthropological assumption that liking those whom we study is a crucial part of our method. ${ }^{35}$ But it is also telling that in the end van Wyk's anthropological teaching leaves her with few tools for elaborating her unhappiness with the church into a firmly grounded judgment upon it. Instead, that training leads her to conclusions very close to those of Haynes. To quote her at some length:

While 'unbelievers' [to whom she presented her work] were shocked by the meanness, selfishness and violence that the...[Universal Church] apparently inspired, 'strong' members insisted that this was part of their warrior ethic. I chose to write about this ethic, not to confirm secular suspicions about the...[Church's]...depravity, but to illustrate the depth of their belief and the fundamentally positive social goals to which their behaviour was ultimately directed. Indeed, [Church] members believed that through sacrifices, 'strong' behaviour and steadfastness they could reinstate God's blessings in the lives of their families; theirs was not a 'selfish' faith. ${ }^{36}$

In the end, van Wyk too ends up arguing that those who attend the Universal Church she studies in Durban are not less than full human beings, possessed of intelligence, moral impulses, and social concern. I applaud her for this, and as an anthropologist I would not have wanted her to come to any different conclusions. But it is worth pointing out that her work shows us clearly that when it comes to the matter of critical judgment, the anthropological spade is turned,

\footnotetext{
$34 \quad$ Ibid., 31.

35 Ilana van Wyk, "Beyond Ethical Imperatives in South African Anthropology: Morally Repugnant and Unlikeable Subjects," Anthropology Southern Africa 36, no. 1-2 (2013): 68-79.

$36 \quad$ Ibid., 75 .
} 
and this is true even when we manage, as van Wyk has, to convey material that seems to cry out for it. This is, I think, an important point of contrast with theologians who deal with world Christianity.

In fact, I have already quoted some of the harsher judgments theologians have made about the prosperity gospel. What interests me now is the theological reasoning processes that lead them to these judgments, reasoning processes in which anthropologists tend not to engage. How is it, I want to ask in anthropological fashion, that theologians can fit such practices of judgment into their own scholarly lives - lives that make sense, I presume, on their own terms?

An initial observation to make is that in the sources I have examined to date, I am impressed with what I take to be a stance of humility theologians tend to maintain in the judgment process. Even the harsh pronouncements I quoted earlier were made by scholars who had done a lot of work to reach their conclusions. And in most texts I have encountered, the authors are careful to refer to their own limits when it comes to rendering judgment on forms of the Christian faith they do not practice. Several are also keenly aware of the caution theologians living relatively comfortable lives in the global North need to exercise when approaching churches that appeal so strongly to those living far more precarious lives. ${ }^{37}$ But theological humility does not go so far as suspending judgment altogether, as one can argue anthropological humility does as a matter of method and sometimes of theory. In the end, theologians are charged with making what Nancy Tanner ${ }^{38}$ refers to as "normative theological judgments - judgments about what is authentically Christian" - and it is from this vantage point that they ultimately approach the prosperity gospel.

Within the texts I have consulted, the process of reaching such judgments tends to proceed along one of two lines. Some check the accuracy of the biblical pronouncements of prosperity preachers against other, more widely academically acceptable ways of interpreting the text. The well-known Pentecostal biblical scholar, Gordon Fee, ${ }^{39}$ takes this approach, finding prosperity

37 Amos Yong, "A Typology of Prosperity Theology: A Religious Economy of Global Renewal or a Renewal Economics," in Pentecostalism and Prosperity: The Socio-Economics of the Global Charismatic Movement, eds. K. Attanasi and A. Yong (New York: Palgrave, 2012), 20-21; see Mika Vähäkangas, "The Prosperity Gospel in the African Diaspora: Unethical Theory or Gospel in Context," Exchange 44 (2015): 353-380.

38 Kathryn Tanner, "Theology and Cultural Contest in the University," in Religious Studies, Theology, and the University: Conflicting Maps, Changing Terrain, eds. L.E. Cady and D. Brown (Albany: State University of New York Press, 2002), 203.

39 Gordon D. Fee, The Disease of the Health and Wealth Gospel (Vancouver: Regent College Publishing, 2006), 9 . 
interpretations to be "purely subjective and arbitrary" $40 \mathrm{He}$ offers as a case in point a common prosperity understanding of $3 \mathrm{~J}$ John 2 . In the King James Version, this reads, "Beloved, I wish above all things that thou mayest prosper and be in health, even as thy soul prospereth." If one returns to the Greek and explores the way the language was used at the time this was written, $\mathrm{Fee}^{41}$ points out that it is clear that this is merely a standard formal greeting, like "I hope all is well with you," and not an assertion that we should or that we have a right to prosper.

An expanded form of such critiques based in biblical scholarship and hermeneutic criticism checks the prosperity gospel against "traditional Christian teachings" more broadly and finds it wanting. ${ }^{42}$ In this form of critique, it is common to note that the roots of the prosperity gospel are not solely Christian, for New Thought and gnostic ideas were also in the mix from the origins of the movement in the United States. ${ }^{43}$ Likewise, the prosperity tendency to assert that the Bible is in effect a contract with believers, and that those who pray strongly and tithe regularly obligate God to deliver them blessings, are often classed as magical practices that do not recognize the traditionally normative Christian notions of God's sovereign freedom. ${ }^{44}$ This point is tied to another, to which I will return, which is that the prosperity gospel may well have a theological anthropology that is too "high," ${ }^{45}$ defining human beings as capable of too much, and God, correlatively, of too little.

A second line of critical investigation does not set the Prosperity gospel against the measuring stick of the Bible or the Christian tradition, but instead looks more closely at the situations in which followers of the prosperity gospel live their lives, and asks in correlational or contextual terms whether it succeeds in rendering the Christian message meaningful for them in their own circumstances. This work can sometimes make use of anthropological methods and even findings as it aims to capture the "complicated" lives that prosperity believers live. Mika Vähäkangas ${ }^{46}$ draws on Haynes' work in this way to

$40 \quad$ See also Starner, "Prosperity Theology," 396.

41 Fee, The Disease, 10.

42 Wolfgang Vondey, Pentecostalism: A Guide for the Perplexed (London: Bloomsbury, 2013), 103 .

43 Ackerley, Importing Faith; Kate Bowler, Blessed: A History of the American Prosperity Gospel (Oxford: Oxford University Press, 2013); Ogbu Kalu, African Pentecostalism: An Introduction (New York: Oxford University Press, 2008). Milmon F. Harrison, Righteous Riches: The Word of Faith Movement in Contemporary African American Religion (New York: Oxford University Press, 2005), 9.

45 Bowler, Blessed, 31; Vondey, Pentecostalism, 101.

46 Vähäkangas, "The Prosperity Gospel." 
point out that African migrants in Finland define prosperity in social relational terms in the course of making an argument that traditional African concerns, as much as or even more than neo-liberal ones, are part of the foundations of their faith. But in theological hands, embedding the prosperity gospel in the wider social contexts of which it forms a part are not a substitute for judgment, but a prelude to it. For there is always the possibility for contextualization to go too far, becoming in the cases under consideration what the Pentecostal theologian Frank Macchia ${ }^{47}$ calls "a heretical accommodation of the gospel to the larger cult of personal prosperity" that "lacks faithfulness to vital elements of the gospel that might challenge the priorities of capitalist economics" or that similarly takes too accommodating an approach to indigenous cultural concerns it may have come to address. In this spirit, Vähäkangas ${ }^{48}$ ends his largely positive contextual account of the migrant churches he studied in Helsinki by acknowledging that, "the unanswered question that we are left with is whether a church whose message is aimed almost exclusively at the successful and socially attractive (and those en route) can really be a church for all." Thus, even when theologians tack closest to anthropologists in their approach to the prosperity gospel, the call to judgment remains to prevent any collapse of disciplinary identities.

\section{Conclusion}

Having arranged a meeting between anthropology and theology on the globally expansive grounds of the prosperity gospel, I want to bring my discussion to a conclusion by considering what this encounter may tell us about the prospects for a mutually transformative dialogue between the two disciplines. I will focus on two issues around which I think such a dialogue can be productive. One - that of judgment - I have already extensively introduced. The other, having to do with what were for me at least some unforeseen similarities in both disciplines' fundamental views of humanity, I will turn to in closing out my discussion.

The finding that one thing that renders anthropology and theology different from each other is that the practices of judgment are central to theology and almost forbidden in anthropology may seem a bit too obvious to bear even the

\footnotetext{
47 Frank D. Macchia, "A Call for Careful Discernment: A Theological Response to Prosperity Preaching," in Pentecostalism and Prosperity: The Socio-Economics of the Global Charismatic Movement, eds. K. Attanasi and A. Yong (New York: Palgrave, 2012), 232.

Vähäkangas, "The Prosperity Gospel," 379.
} 
attention I have already given it. Those who have been through the battles that beset the relationship between religious studies and theology must feel like they have heard some version of this kind of observation before. But the framework of those discussions tends to be set by the notion of normativity - the key question being how can disciplines that are normative and those that are not sit side by side? I have very deliberately avoided that framework by choosing judgment as the axis around which my argument has turned. Granted, normativity and judgment are closely related, but they are not the same. And if it is common now, and not only for postmodernists, to acknowledge that all disciplines are inescapably normative whether they admit it or not, it is an observable feature of academic life that not all disciplines aim at rendering explicit judgments on the objects they study. It is in this respect that theology and anthropology clearly differ. ${ }^{49}$

More than that, to understand anthropology fully, I think it is important to realize that its suspension of judgment does not just follow from worries about how normative commitments can compromise objectivity, but also from the role played by the positive doctrine of relativism, itself once normative in the discipline, in rendering the withholding of judgment a virtuous act. Remember, anthropology is the discipline that once registered an official dissent during the comment period for the 1948 UN Declaration of Human Rights, expressing concern that the Declaration's focus on the claims of individuals might be culture-bound. It should come as no surprise, then, that for generations anthropologists have been carefully (if often implicitly) trained in how to withhold judgment, leading them to test themselves against all kinds of ethnographic reports that challenge their own normative sensibilities and to learn to bracket those sensibilities in order to work toward figuring out how all groups of people make sense in their own terms. This educational tradition has a lot to do with the discipline's unique place in the intellectual universe. But the emphasis on it has also meant that anthropologists are not well trained in making judgments when they might want to - and in this respect, they have a lot to learn from theology about how to judge with humility on the basis of explicit standards that have been hammered out over long periods of scholarly effort. For reasons I cannot go into here, I think that anthropological relativism is in

49 I was first led to consider judgment as a key topic when thinking about the differences between anthropology and theology by discussions with Patrick McKearney and readings of early versions of his 2016 article, Patrick McKearney, "The Genre of Judgment," Journal of Religious Ethics 44 (2016): 544-573. I thank him for setting me on this track. 
disarray these days. Personally, I hope it will survive in some form. But whether it does or not, its current difficulties suggest that the time is right for anthropologists, more and more interested in rendering frank judgments, to come into dialogue with theologians about the role of judgment in their tradition, and the ways its practice is best cultivated and carried out.

Since I am not a theologian, I find it more awkward to pronounce on what theologians might learn from anthropologists about matters of judgment. But perhaps inverting the argument I just made could indicate one angle of approach. In a sense, I have so far suggested that even if anthropologists do not seek in theology to discover what specific judgments about the world they should make, they can learn from theology about responsible ways of making any kind of judgments at all. Turning this around, theologians might learn from anthropologists about the depth and complexity of the kinds of cultural expressions they are often called upon to judge. Anthropologists of Christianity have by now learned a lot about the very wide range of things Christians around the world value, and the grounds for the judgments these Christians have made. Theologians might take from anthropologists some lessons about how keeping this kind of variation constantly in mind might inform their own ways of judgment.

I could have made this argument about the potential benefits of a dialogue between anthropology and theology about judgment even without discussing the two parties' divergent approaches to the prosperity gospel. But given the challenges this kind of Christianity presents to those in both disciplines, I think that discussion helped to focus some of the issues in play. The other topic that I want to suggest is ripe for consideration between the two fields is one that might not have stood out so clearly without the provocations the prosperity gospel provides. I have already noted that some theologians worry about the very high theological anthropology that underwrites prosperity doctrine. It holds that believers have great power, and that they can assure their own salvation through the cultivation of strong faith. In this scheme, God has little to do beyond meeting his obligations when believers meet theirs. It is the power accorded to human action in this scheme that I think leads some theologians and anthropologists alike to class it as very nearly a form of magic.

Working at the edges of my knowledge for a moment, I am going to guess that there may be relatively few academic theologians who subscribe to a vision of humanity that gives individuals quite so much power of their own and expects that, by themselves, human beings can wholly control their own spiritual and material destinies. And put in just this very general way, one that sets God and salvation aside, I can say with more confidence that anthropologists 
are right there with theologians on this point. The philosophical anthropology that underwrites anthropology emphasizes, as Clifford Geertz ${ }^{50}$ famously put it, that human beings are incomplete animals. All of them require, as his theoretical framework has it, upbringing in a culture to allow them to make anything of their lives. Other anthropological theorists would stress human dependence on social relations and society more generally where Geertz stresses culture, but all of them come together in the broad belief that individuals are never able to create truly human lives on their own. Anthropology, then, is a discipline founded on a notion of the human lack of self-sufficiency. What human beings on their own lack in various theological traditions is, of course, not quite culture or society, or not only those things, but still, the sense that individuals on their own are not able to reach their greatest potential seems to me a key assumption of theological anthropology as well. It is little wonder, then, that we both tend to recoil from what one theologian calls the "triumphalism," or I might call the "individualist triumphalism," of the prosperity gospel. We share a kindred sense that along with whatever else this kind of faith might get wrong, it misses the ways in which human individuals need more than themselves and their own ambitions and drives to reach their highest development. ${ }^{51}$

So, this matter of human incompleteness is another topic around which anthropologists and theologians might start a mutually transformative conversation. I cannot yet really predict how such a conversation might go, and I have not left space to explore how this theme of human incompleteness and that of judgment might relate to each other. But I hope that taken together they indicate some of the promise of the dialogue these two disciplines, recently shaken out of some longstanding routines and thrown together out of their need to come to grips with a larger world then they formerly reckoned with, might begin to undertake.

\section{References}

Ackerley, Glyn J. Importing Faith: The Effect of American “Word of Faith” Culture on Contemporary English Evangelical Revivalism. Eugene, Oregon: Pickwick Publications, 2015 .

5o Clifford Geertz, The Interpretation of Cultures (New York: Basic Books, 1973), 46-47, 218.

$5^{1} \quad$ Vondey, Pentecostalism, ch. 5 . 
Attanasi, Katherine. "The Plurality of Prosperity Theologies and Pentecostalism." In Pentecostalism and Prosperity: The Socio-Economics of the Global Charismatic Movement edited by K. Attanasi and A. Yong, 1-12. New York: Palgrave, 2012.

Borneman, John and Abdellah Hammoudi. "The Fieldwork Encounter, Experience, and the Making of Truth: An Introduction." In Being There: The Fieldwork Encounter and the Making of Truth, edited by J. Borneman and A. Hammoudi, 1-24. Berkeley: University of California Press, 2009.

Bowler, Kate. Blessed: A History of the American Prosperity Gospel. Oxford: Oxford University Press, 2013.

Coleman, Simon. The Globalisation of Charismatic Christianity: Spreading the Gospel of Prosperity. Cambridge: Cambridge University Press, 2000.

Comaroff, Jean and John L. Comaroff. "Occult Economies and the Violence of Abstraction: Notes from the South African Postcolony." American Ethnologist 26, no. 2 (1999): 279-303.

Daswani, Girish. "A Prophet but not for Profit: Ethical Value and Character in Ghanaian Pentecostalism." Journal of the Royal Anthropological Institute 22 (2015): 108-126.

Douglas, Bronwen. "From Invisible Christians to Gothic Theatre: The Romance of the Millennial in Melanesian Anthropology." Current Anthropology 42, no.1 (2001): $615^{-6} 5^{\circ}$.

Fee, Gordon D. The Disease of the Health and Wealth Gospel. Vancouver: Regent College Publishing, 2006.

Geertz, Clifford. The Interpretation of Cultures. New York: Basic Books, 1973.

Harding, Susan. "Representing Fundamentalism: The Problem of the Repugnant Cultural Other." Social Research 58, no. 2 (1991): 373-393.

Harrison, Milmon F. Righteous Riches: The Word of Faith Movement in Contemporary African American Religion. New York: Oxford University Press, 2005.

Haynes, Naomi. "Pentecostalism and the Morality of Money: Prosperity, Inequality, and Religious Sociality on the Zambian Copperbelt." Journal of the Royal Anthropological Institute 18 (2012): 123-139.

Howell, Brian. "Practical Belief and the Localization of Christianity: Pentecostal and Denominational Christianity in Global/Local Perspective." Religion 33, no. 3 (2003): 233-248.

Kalu, Ogbu. African Pentecostalism: An Introduction. New York: Oxford University Press, 2008.

Keane, Webb. "Self-Interpretation, Agency, and the Objects of Anthropology: Reflections on a Genealogy." Comparative Studies in Society and History 45 (2003): $222-248$.

Macchia, Frank D. "A Call for Careful Discernment: A Theological Response to Prosperity Preaching." In Pentecostalism and Prosperity: The Socio-Economics of the Global 
Charismatic Movement, edited by K. Attanasi and A. Yong, 225-238. New York: Palgrave, 2012.

McKearney, Patrick. “The Genre of Judgment." Journal of Religious Ethics 44 (2016): 544-573.

Nolivos, Eloy H. "Capitalism and Pentecostalism in Latin America: Trajectories of Prosperity and Development." In Pentecostalism and Prosperity: The Socio-Economics of the Global Charismatic Movement, edited by K. Attanasi and A. Yong, 87-106. New York: Palgrave, 2012.

Noll, Mark A. From Every Tribe and Nation: A Historian's Discovery of the Global Christian Story. Grand Rapids: Baker Academic, 2014.

Percy, Martyn. “Forward." In Importing Faith: The Effect of American “Word of Faith” Culture on Contemporary English Evangelical Revivalism, edited by G.J. Ackerley, vii-xi. Eugene, Oregon: Pickwick Publications, 2015.

Robbins, Joel. "On Not Knowing Other Minds: Confession, Intention, and Linguistic Exchange in a Papua New Guinea Community." Anthropological Quarterly 81, no. 2 (2008): 421-429.

Robbins, Joel. "Transcendence and the Anthropology of Christianity: Language, Change, and Individualism" (Edward Westermarck Memorial Lecture, October 2011.) Journal of the Finnish Anthropological Society 37, no. 2 (2012): 5-23.

Robbins, Joel. "The Anthropology of Christianity: Unity, Diversity, New Directions" (An Introduction to Supplement 10). Current Anthropology 55 (S10) (2014): S157-S171.

Robert, Dana L. "Shifting Southward: Global Christianity Since 1945." International Bulletin of Mission Research 24, no. 2 (2000): 50-58.

Schieffelin, Edward L. The Sorrow of the Lonely and the Burning of the Dancers. New York: St. Martin's Press, 1976.

Shaw, Mark. "Robert Wuthnow and World Christianity: A Response to Boundless Faith." International Bulletin of Mission Research 36 no. 4 (2012): 179-184.

Starner, Rob. "Prosperity Theology." In Encyclopedia of Pentecostal and Charismatic Christianity, edited by S.M. Burgess, 392-397. New York: Routledge, 2006.

Tanner, Kathryn. "Theology and Cultural Contest in the University." In Religious Studies, Theology, and the University: Conflicting Maps, Changing Terrain, edited by L.E. Cady and D. Brown, 199-212. Albany: State University of New York Press, 2002.

Vähäkangas, Mika. "The Prosperity Gospel in the African Diaspora: Unethical Theology or Gospel in Context." Exchange 44 (2015): 353-380.

van Wyk, Ilana. "Beyond Ethical Imperatives in South African Anthropology: Morally Repugnant and Unlikeable Subjects." Anthropology Southern Africa 36, no. 1-2 (2013): 68-79.

van Wyk, Ilana. The Universal Church of the Kingdom of God in South Africa: A Church of Strangers. Cambridge: Cambridge University Press, 2014.

Vondey, Wolfgang. Pentecostalism: A Guide for the Perplexed. London: Bloomsbury, 2013. 
Wardlow, Holly. Wayward Women: Sexuality and Agency in a New Guinea Society. Berkeley: University of California Press, 2006.

Wariboko, Nimi. "Pentecostal Paradigms of National Economic Prosperity in Africa." In Pentecostalism and Prosperity: The Socio-Economics of the Global Charismatic Movement, edited by K. Attanasi and A. Yong, 35-59. New York: Palgrave, 2012.

Wuthnow, Robert. Boundless Faith: The Global Outreach of American Churches. Berkeley: University of California Press, 2009.

Yong, Amos. "A Typology of Prosperity Theology: A Religious Economy of Global Renewal or a Renewal Economics." In Pentecostalism and Prosperity: The SocioEconomics of the Global Charismatic Movement, edited by K. Attanasi and A. Yong, 15-34. New York: Palgrave, 2012. 